\title{
CAUSES AND DETERMINATIONS OF SECURITY RISK - ANALYSIS AND PERSPECTIVE OF CONFLICTS IN UKRAINE Laura-Lucia RĂŞINAR
}

\author{
“Nicolae Bălcescu” Land Forces Academy, Sibiu, lucicut13@yahoo.com
}

\begin{abstract}
Risks are difficult to combat, especially when they are diverse and influenced by so many factors from the security environment. Because of the rapid and dynamic changes, risks are important to be discovered, understood and eliminated. The main problem is how to anticipate them and prevent any bad event to happen. This shows the importance of intelligence services and cooperation between states in assuring security to prevent conflicts. Any conflict is considered to be the result of poor communication and cooperation between states and low efficiency in anticipating the evolution of international relationships in the area. How could everything evolve in Ukraine in a better environment of communication and prevention? How could the risks and crisis be avoided and what kind of effects can we pass in review today? But the most important aspect remains how to never let this happen again.
\end{abstract}

\section{Keywords: Hybrid conflict, security risk, conflict prevention, strategic interests}

\section{Introduction}

Throughout the 1990s, the main actors have paid extensive attention to conflict prevention because of the importance of avoiding conflicts with great negative impact. Preventive actions are designed to resolve, manage, or contain disputes before they become violent. The notion of conflict prevention includes numerous activities such as conflict avoidance and conflict resolution, with techniques such as mediation, peace-keeping, peacemaking, confidence-building measures, and tracktwo diplomacy. In order to be able to prevent a conflict, the actor needs to know all the causes and determinations of the risks in the area. In the peacemaking or peacekeeping process, one has to know and understand all the aspects of the conflict: history, political views, economy, diplomacy and many others. In many of these categories there is a risk or vulnerability [1].

Despite all struggles of the international community, conflicts continue to emerge and many of them turn violent. In the 1990s decade alone, approximately 5.5 million people were killed in almost 100 armed conflicts. These deadly conflicts have led to widespread devastation and regional instabilities, as well as large numbers of refugees. The most important and urgent subject in attention is to prevent a conflict that could be called The 3rd World War. This event takes place when actors, states or organizations, have different interests and build opposing coalitions. This happens because a crisis in a small area can affect everybody in many ways, as a result of the globalization process [2].

2. Prevention of a conflict and the impact of political interests

The dynamics of conflicts consists in a multitude of specific indicators, such as poverty and high population growth, resource scarcity, discrimination and disempowerment of minorities and other groups in society, military threats and sources of insecurity. 
A certain mix of these variables can, but must not necessarily, lead to societal stress, violence and war [3].

Every action of an actor has an effect. Every step made by a state will have a result. Maybe the most difficult steps are made in the international relationships field and, of course, the feedback will be received with effects in the other fields as economy, security, health, infrastructure and others. This is the reason why the decisions taken by leaders are the most important. The proximate causes of conflict often result from deliberate decisions by determined leaders or political demagogues to make violent responses to contentious issues.

As a result, bad leadership can exploit insecurity, the vulnerability of certain groups and socio-economic cleavages. In order to understand the dynamics of a conflict and the effect of the failure in preventing it, it is interesting to take a look upon the opinion of some political leaders about Ukraine.

Of course, the words are sometimes contradicted by the facts. While more and more Russian military movements are taking place in Ukraine, Vladimir Putin sustains: "Europe is just as interested in that as Russia. No one wants conflict on the edge of Europe; especially armed conflict [...] I think that such an apocalyptic scenario is unlikely and I hope this will never happen" [4]. At the same time, while they analyze the possibility of sending equipment in Ukraine, Barack Obama said that the chances for a military solution in Ukraine were low and "If Russia continues its aggressive actions in Ukraine, including by sending troops, weapons and financing to support the separatists, the costs for Russia will rise" [5].

On the contrary, Germany's Angela Merkel said that sending arms to help Ukraine fight pro-Russian separatists would not solve the crisis there. Merkel pledged the support of all German ministries - from finance, economy and the foreign office to development - to help and advise Ukraine when it came to making the country economically successful and transparent. She also sustained that "The German economy will be prepared in the next few months to discuss with Ukraine what investment options will become available" [6].

One of the most important actors, China, does not condemn Russia: "The West should abandon the zero-sum mentality, and take the real security concerns of Russia into consideration" [7]. China has also been cautious not to be drawn into the struggle between Russia and the West over Ukraine's future, not wanting to alienate a key ally. It has said it would like to continue to develop friendly cooperation with Ukraine, and respects the ex-Soviet state's independence, sovereignty and territorial integrity. While Beijing officially supports Russia's position on its annexation of Crimea, behind the scenes China is helping keep the battered Ukrainian economy afloat. On March 26 2015, the Ukrainian government and China's CITIC Construction (a subsidiary of CITIC Ltd.) signed a memorandum of understanding stipulating that Ukraine will receive $\$ 15$ billion from China at a minimal interest rate for 15 years to build housing and attendant infrastructure [8].

Although Romania and Poland don't have the size and power of USA, Russia or China, they are key members of NATO organization because of their geographical position. In this context, their opinion about the conflict is very important. Poland will provide training to around 50 Ukrainian army instructors in 2015. Poland has been one of the most outspoken critics of Russian policy towards a pro-Russian separatist rebellion in eastern Ukraine, joining Western allies in accusing Moscow of supplying help to the insurrection something the Kremlin denies [9].

The Romanian President Klaus Iohannis said that Romania is supporting Ukraine's sovereignty, unity and territorial integrity, underscoring Romania's wish to be an 
active factor in the find of political solutions to the eastern Ukraine crisis: „Romania wants to be an active factor in the find of political solutions to the eastern Ukraine crisis, in the promotion of democracy and peace in the region. We are interested in having a neighbor that is firmly committed to democratic consolidation and its path to Europeanization" [10].

It is clear that each side has its own interests, but once a conflict has been started, it brings losses to every actor involved one way or another. This is why the best solution is to prevent any conflict from taking place and the interests of leaders show how many risks and vulnerabilities are taken into consideration.

\section{Statement before Ukraine conflict}

To understand the security risks in an area is important to have a view on the main interests and capabilities of the main actors involved. These aspects which will be presented are the main causes of security risks for Ukraine and other states in the area.

First of all, the Russian military suffered years of neglect after the Soviet collapse and no longer cast the shadow of a global superpower. However, the Russian armed forces are in the midst of a historic overhaul with significant consequences for Eurasian politics and security. Russian conventional forces dwarf those of its Eastern European and Central Asian neighbors, as it can be seen in the table.

Table no. 1: Military capabilities [11]

\begin{tabular}{|c|c|c|c|}
\hline Caungr & Tracos [xtive| & Tanks & Cambat A rraft \\
\hline FLSSIA & migoo & 27,000 & 1,357 \\
\hline AALER A & 44,E00 & 109 & 15 \\
\hline AxEREALIA & Es,ess & 430 & 44 \\
\hline BELAFUS & 48000 & 515 & 12 \\
\hline GeOACLA & 2016s: & 121 & 12 \\
\hline MAZEMHSTLE & 37,0: & so & $12 z$ \\
\hline KATtYISTEM & id sto & 150 & 33 \\
\hline HoLDors & 5,350 & 0 & $\mathbf{0}$ \\
\hline TAJXISTR & a,s50 & 37 & 0 \\
\hline TUAK MF MSTAY & 22,000 & ata & 94 \\
\hline UrFAR & 121.500 & $\mathrm{ned}$ & No \\
\hline URBENISTA & LE,paO & 340 & 135 \\
\hline
\end{tabular}

Russia has a military pact with Armenia, Belarus, Kazakhstan, Kyrgyzstan, and Tajikistan through the Collective Security Treaty Organization, formed in 1992. Moscow also stations troops in the region: Armenia, Georgia's breakaway regions of Abkhazia and South Ossetia, Moldova's separatist Transnistria region, Kyrgyzstan, Tajikistan, and Crimea.

Also, Moscow is intent on remilitarizing its
Arctic territory and is restoring Soviet-era airfields and ports to help protect important hydrocarbon resources and shipping lanes. In late 2013, Putin ordered the creation of a new strategic military command in the Russian Arctic.

Meanwhile, rearmament has been slow, and much of the military's equipment remains decades old. All of the navy's large vessels, including its sole aircraft carrier, the non- 
nuclear Kuznetsov, are holdovers from the Cold War. By comparison, the United States has ten nuclear carriers and builds several new warships each year.

The Russian air force remains the secondlargest in the world, with approximately 2,500 aircraft in service, but most date from the 1980s. New variations of the Sukhoi Flanker, a multi-role fighter, are expected to serve as Russia's main combat aircraft for at least the next the decade.

Russia's vast nuclear arsenal remains on par with the United States and is the country's only residual great power feature, according to military analysts. Moscow keeps about 1,500 strategic warheads on deployed intercontinental ballistic missiles, submarines, and heavy bombers. Russia is also believed to have a few thousand nonstrategic nuclear weapons, which are lower-yield munitions that can be deployed and used on the battlefield.

Russian leaders acknowledge that there is now little threat of a large-scale NATO land invasion a top concern during the Cold War but they repeatedly condemn the bloc's eastward expansion, including its plans to roll out a ballistic missile defense shield across Europe.

Military modernization will enable the world's largest country by far (and one of the most sparsely populated) to better defend its vast territory and national interests. But the conflicts in Ukraine and Georgia have aroused concerns about Putin's willingness to use military force to preserve Russia's traditional sphere of influence.

Looking ahead, states that border Russia are chiefly concerned with its hybrid warfare capabilities [12], which by many accounts were deployed successfully in Crimea and to a lesser extent in Eastern Ukraine [13].

Recent developments have also exposed unresolved tensions over NATO's expansion into the former Soviet sphere. Many current and former Russian leaders believe the alliance's inroads into the former Soviet sphere are a clear betrayal of alleged guarantees to not expand eastward after German reunification in 1990. Moscow has viewed NATO's post-Cold War expansion into Central and Eastern Europe with great concern. Many current and former Russian leaders believe the alliances inroads into the former Soviet sphere are a betrayal of alleged guarantees to not expand eastward after German reunification in 1990 although some U.S. officials involved in these discussions dispute this pledge.

As a result, in an address honoring the annexation of Crimea that month, President Vladimir Putin expounded Russia's deepseated grievances with the alliance. "They have lied to us many times, made decisions behind our backs and placed us before an accomplished fact. This happened with NATO's expansion to the East, as well as the deployment of military infrastructure at our borders," Putin told Russia's parliament. "In short, we have every reason to assume that the infamous [Western] policy of containment, led in the eighteenth, nineteenth, and twentieth century's, continues today" [14].

In early 2015, fears of further Russian aggression have prompted alliance leaders to reassess defenses on the continent, particularly in the East. NATO allies agreed to establish new command centers in six eastern periphery states: Bulgaria, Estonia, Latvia, Lithuania, Poland, and Romania [15].

All these aspects describe rivals in a continuous competition. Every action made by one, is considered a threat by the other. In this context, the expansion of NATO was perceived by Russia as a threat against security and, as a result, a response is necessary.

All these are general aspects, which can be taken into consideration in every conflict. On the other side, it is important to understand the facts, risks and vulnerabilities of the state that is most involved in the conflict. There are some essential aspects about Ukraine and Crimea in the past. First of all, in 1944 Stalin 
deported 200,000 Crimean Tatars to Siberia and Central Asia following accusations of collaboration with Nazi Germany. After about 50 years, about 250,000 Crimean Tatars and their descendants return to Crimea following collapse of Soviet Union. But in 1954, Soviet leader Nikita Khrushchev transferred the Crimean peninsula to Ukraine as a gift.

Despite this, when the revolutions in other countries took place, in 1991 Ukraine declared independence following attempted coup in Moscow: $90 \%$ vote for independence in nationwide referendum in December.

In some fields, there were partnerships between Russia and Ukraine. In 1997, a friendship treaty signed with Russia. Ukraine and Russia also reach agreement on the Black Sea fleet. On the other side, Ukraine announced in 2002 the decision to launch formal bid to join NATO. But after this measure, some steps back were made. In 2004 Ukraine ignored protests from EU and Romania by opening canal in the Danube delta which will link with Black Sea, rejecting claims that it will cause environmental damage. In the end, in 2010 the Parliament votes to abandon NATO membership aspirations. But these events were doubled by the fact that in 2009 Russia stopped all gas supplies to Ukraine after collapse of talks to end row over unpaid bills and prices, leading to shortages in southeast Europe. Supplies are restored a week later when Ukraine and Russia sign a 10 -year deal on gas transit. One year later, Ukraine agrees to eliminate its stockpile of weapons-grade nuclear material ahead of the Washington nuclear security summit.

Parliament ratifies an agreement to extend Russia's lease on the Black Sea fleet base at Sevastopol in Crimea for 25 years, in return for cheaper gas imports [16].

As a result, Ukraine remained all the time a country of instability when it came to partnership with Russia or NATO and Western countries. This is a great vulnerability because it puts the state in an unsecured position in the international relationships sphere. This was the unstable situation that generated conflict and couldn't be predicted or prevented in any way. As it can be seen, there are causes and determinations as rivals among the main actors of the Earth, interests, strategy for better economy, but also local vulnerabilities as unstable environment, social conflicts, protests and disagreements. The results are clear: a great danger, many losses and insecurity in the entire area.

\section{Conclusion}

Taking into consideration all the aspects presented, it is clear that a conflict involves many losses for every entity. This is why the leaders avoid open conflicts.

In the last several months many subjects as recruiting civilians were discussed in the media. It is true that Poland has already many volunteers in the army, while in Romania many people are worried and mainly against any military service. This also represents a vulnerability of the states. NATO and other efficient organizations are based on trust and support. We must trust that our partners are participating with us and they must trust that we are capable. This is the reality in a true alliance.

Countries as Ukraine and the Republic of Moldova will always sit between NATO, EU and Russia. They will probably never or very hard be members of NATO or EU. Therefore, the primary purpose must be the social security and peace building in the area. The Black Sea area, the gas from Russia, the social security and the reconstruction of damaged areas are top priorities and aspects of interest in maintaining peace and avoiding a great conflict. 


\section{References}

[1] Marc Andre Franche, Michi Ebata, Conflict prevention - thematic guidance note, 2004, United Nations Development Programme p. 4

[2] Neculai Stoina, Globalizarea politicii internaţionale, Sibiu, "Nicolae Bălcescu" Land Forces Academy Publishing House, 2008, p 18

[3] Paul Dobrescu, Geopolitica, Bucharest, Comunicare.ro Publishing House, 2003, p 168.

[4] http://www.bbc.com/news/world-europe-31596634

[5] http://edition.cnn.com/2015/02/10/politics/obama-putin-ukraine/

[6] http://www.dw.de/merkel-ukraine-calmer-but-still-short-of-ceasefire/a-18357315

[7] http://www.reuters.com/article/2015/02/27/us-china-ukraine-idUSKBN0LV0H120150227

[8] http://www.jamestown.org/programs/edm/single/?tx_ttnews\%5Btt_news\%5D= 43740\&cHash=e6cb2fd34b5fe5b45207046561df1ce2\#.VSFHytysUQN

[9] http://www.reuters.com/article/2015/03/31/us-ukraine-crisis-polandidUSKBN0MR0KU20150331

[10] http://www.agerpres.ro/english/2015/03/17/iohannis-romania-wants-to-be-active-factorin-finding-political-solutions-to-eastern-ukraine-crisis-11-05-29

[11] Created by the author, based on http://www.globalfirepower.com

[12] Aurelian Raţiu, Gestionarea dinamicii conflictelor asimetrice, "Nicolae Bălcescu" Land Forces Academy Publishing House, Sibiu, 2012, pp. 51-55

[13] http://www.cfr.org/russian-federation/russian-military/p33758

[14] http://rt.com/politics/official-word/vladimir-putin-crimea-address-658/

[15] http://www.cfr.org/nato/north-atlantic-treaty-organization-nato/p28287

[16] http://www.bbc.com/news/world-europe-18010123 